\title{
An evaluation of water quality at Sandhill Wetland: implications for reclaiming wetlands above soft tailings deposits in northern Alberta, Canada
}

\author{
Jeremy A. Hartsock (D) J Jessica Piercey • Melissa K. House • Dale H. Vitt
}

Received: 19 August 2020/ Accepted: 2 December 2020/Published online: 2 January 2021

(C) The Author(s) 2021

\begin{abstract}
The experimental Sandhill Wetland is the first permanent reclamation of a composite tailings deposit, and annual water quality monitoring is of specific interest for evaluating and predicting longterm reclamation performance. Here, we present water chemistry monitoring data obtained from Sandhill Wetland (years 2009-2019) and compare results to twelve natural reference wetlands and to environmental quality guidelines for Alberta surface waters. By comparing water quality at Sandhill Wetland and natural sites to established guidelines, we can begin to document the natural background water quality of wetlands in the region and examine if guideline exceedances are seen in natural undisturbed environments, or appear only at active reclamation sites. At Sandhill Wetland the dominant ions in near-surface water were bicarbonate, sulfate, chloride, sodium, calcium, and magnesium. Since the first growing season concentrations for these ions have increased
\end{abstract}

Supplementary information The online version of this article (https://doi.org/10.1007/s11273-020-09771-8) contains supplementary material, which is available to authorized users.

J. A. Hartsock $(\bowtie) \cdot$ M. K. House · D. H. Vitt

Department of Biology, Southern Illinois University,

Carbondale, IL 62901, USA

e-mail: hartsock@siu.edu

J. Piercey

Research and Development, Syncrude Canada Ltd., 1125 Lincoln Drive, Life Science IIrm 481, Fort McMurray,

$\mathrm{AB}$, Canada annually, causing concurrent increases in electrical conductivity. In year 2019, water chemistry at Sandhill Wetland was most comparable to regional saline fens, systems that exhibit elevated electrical conductivity and high sodicity. Near-surface water at Sandhill Wetland exceeded water quality guidelines for three substances/properties (dissolved chloride, iron, and total alkalinity) in the most recent year of monitoring. The saline fen natural sites also exceeded water quality guidelines for the same chemical substances/properties, suggesting guideline exceedances are a norm for some natural wetland site types in the region. Of note, in each year of monitoring at Sandhill Wetland, dissolved organic compounds evaluated in sub- and near-surface water were below detection limits.

Keywords Water quality $\cdot$ Sandhill Wetland · Oil sands · Boreal forest - Wetland reclamation · Peatland

\section{Introduction}

In northeastern Alberta, Canada wetlands cover more than 25\% of the Oil Sands Administration Area (OSAA) (Wieder et al. 2016a, 2019). The ecosystem services provided by these systems are numerous and typified by the high amounts of carbon stored and water associated with regional bogs, fens, and marshes (Gorham 1991; Loisel et al. 2014; Devito et al. 2005). 
Open pit mining for bitumen, however, is a major economic focus in the region. Under a full development scenario to extract all oil resources, over $4500 \mathrm{~km}^{2}$ of wetlands within the OSAA could be disturbed (Lee and Cheng 2009). Returning some of this disturbed area back to landscapes that support functional wetland ecosystems via reclamation efforts is a requirement for oil sands operators (Harris 2007). Although several challenges exist to reclaim tailings landscapes back to wetlands, a key challenge to overcome is ensuring water quality at reclaimed sites is suitable for return to the environment (Mitsch and Wang 2000; Thullen et al. 2002; Rousseaua et al. 2008).

Located on the Syncrude Canada Ltd. mineral surface lease, the experimental Sandhill Watershed reclamation site is a full-scale research pilot study. The site was designed to test the feasibility of constructing a watershed capable of supporting a self-sustaining wetland above a composite tailings deposit—a backfilled open pit mine (Wytrykush et al. 2012). The cumulative size of Sandhill Watershed is 52 ha and the wetland residing within (which we refer to as "Sandhill Wetland") is 17 ha (Fig. 1). Year 2013 was the first full growing season tracked for research purposes following wetting with fresh lake water. Several studies have examined temporal and spatial changes of ions associated with water and soil within Sandhill Wetland (Vitt et al. 2016; Hartsock et al. 2016, 2019; Biagi et al. 2019; Vessey et al. 2019; Clark et al. 2019). Over the first three years (2013-2015), Biagi et al. (2019) reported dissolved calcium, magnesium, sodium, sulfate, and chloride concentrations increased annually, and further, using stable isotopes showed the source of ion accumulation primarily stemmed from upward movement of oil sand process water (OSPW; water associated with composite tailings). While previous studies at Sandhill Wetland have focused on the behavior of dominant anions and cations, characterization of micronutrients, trace metals, heavy metals, and other organic compounds has not been done extensively with the exception of Oswald and Carey (2016), who found total mercury ( $\mathrm{THg}$ ) and methylmercury ( $\mathrm{MeHg}$ ) concentrations in sediments were lower than in two nearby natural fens. Because select trace metals and organic compounds are hazardous to biota at low concentrations, determining baseline concentrations of these elements at Sandhill Wetland is important.
The research presented here seeks to update and expand upon the chemical substances previously monitored in water at Sandhill Wetland. Further, this paper is focused on comparing water quality at Sandhill Wetland to natural reference wetlands and to established provincial surface water quality guidelines.

The Alberta government has developed water quality guidelines for the protection of freshwater aquatic life. These guidelines are based on national Canadian Council of Ministers of the Environment (CCME) environmental quality guidelines, and the protocol for guideline development is adapted from United States Environmental Protection Agency methods (Government of Alberta 2018). Monitoring water quality in wetlands residing on oil sands mineral surface leases and understanding if/where exceedances of the existing guidelines may occur is an important step in closing these mine sites after resource development is complete. By comparing water quality at Sandhill Wetland and natural wetlands to established guidelines, we provide valuable regional context for interpretation of water quality results. This work further documents natural wetland water quality in the region and provides insight into if guideline exceedances are the norm (due to environmental factors) or stem from mining activities.

Here, we present water chemistry data obtained from annual water quality monitoring at Sandhill Wetland spanning each growing season from 2013 to 2019. We also present data obtained from groundwater monitoring wells four years prior to site construction completion (years 2009, 2011, and 2012) to highlight baseline ion concentrations of water residing below the watershed. Lastly, we present water chemistry data obtained from several mature natural reference wetlands that represent potential successional outcomes for Sandhill Wetland. Our primary objectives are threefold: (1) compile and summarize ion concentrations measured at Sandhill Wetland over a ten year period, (2) determine whether ion concentrations at Sandhill Wetland are comparable to observations among natural reference wetlands, and (3) compare water quality among all sites to the Environmental Quality Guidelines for Alberta Surface Waters to examine if/where guideline exceedances occur. 


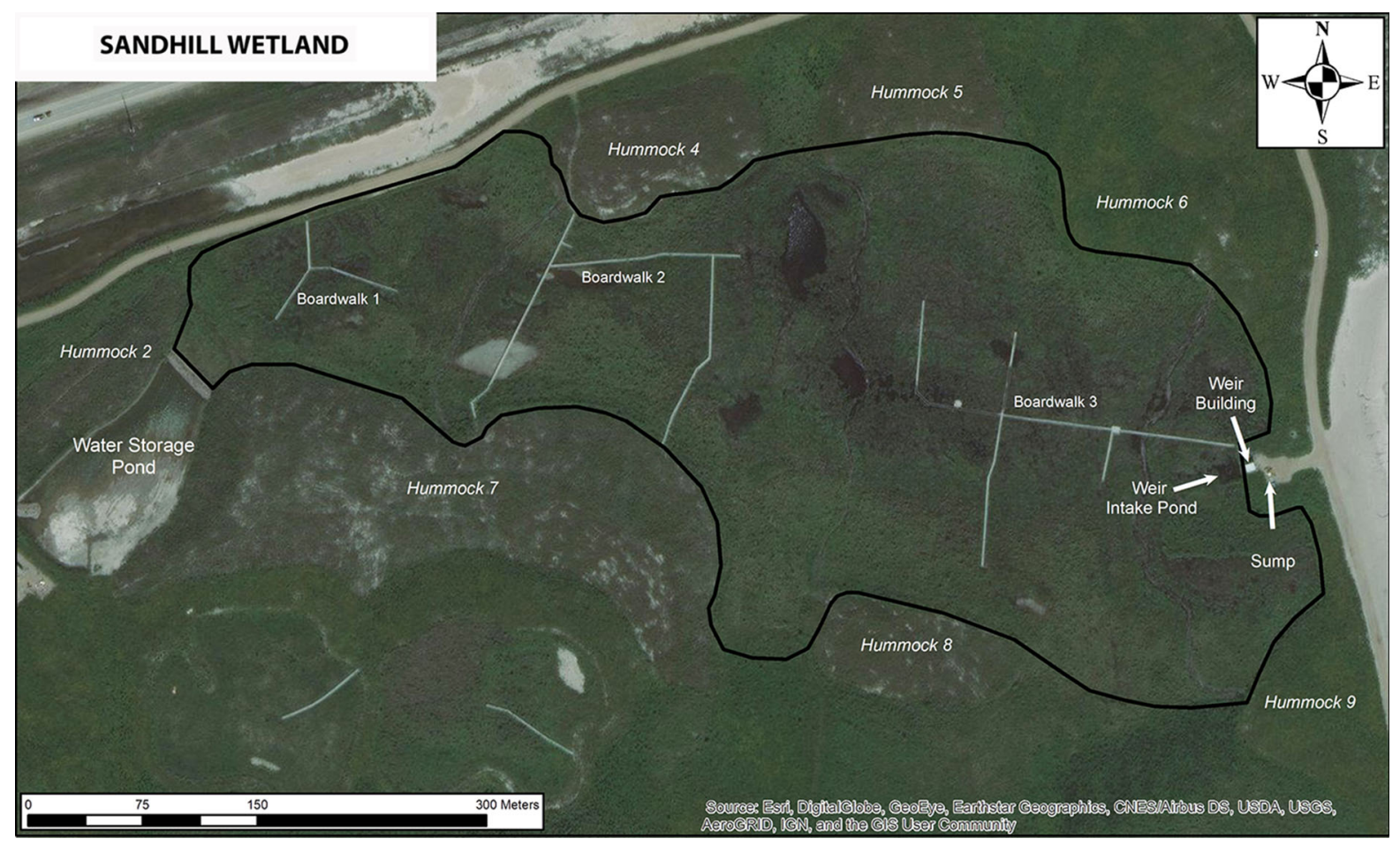

Fig. 1 Map of Sandhill Wetland features (photo obtained from Google Earth year 2018). The black boarder delineates the wetland area from the adjacent uplands. In general, water flows across the site from west to east. Most near-surface water sampling was completed in proximity to the weir intake pond,

\section{Methods}

\section{Sandhill watershed background}

The Sandhill Watershed design included placing various materials at prescribed depths and configurations above a composite tailings deposit. Composite tailings are a mixture of course and fluid fine tailings with gypsum added post-processing to promote aggregation of soft tailings (Oil Sands Wetland Working Group 2014). Composite tailings are poured back into mined-out pits in a slurry using OSPW. Oil sand process water contains high concentrations of soluble salts originating from naturally occurring marine sediments in the region and also added during bitumen recovery (MacKinnon et al. 2001; Chalaturnyk et al. 2002; Matthews et al. 2002). To allow access, promote trafficability, and reach the final elevation for the deposit, a $10 \mathrm{~m}$ tailings sand cap was placed across the entire research site. Of note, an underdrain system was installed within the tailings weir building, and sump (areas collectively referred to as the "outlet"). The rational for collecting water at the outlet was that water quality at the outflow location would be representative of water quality leaving the site. In later years (2018-2019) samples were also collected in proximity to boardwalks $1-3$

sand layer to circumvent possible upward movement of OSPW. When in operation, water within the sand cap collects in the underdrain system and flows to a sump at the watershed outlet. Underdrain water mixes with surface water at the outlet location, where it is then pumped out of the watershed. Overtop the tailings sand, a $0.5 \mathrm{~m}$ layer of clay till was placed in the wetland area that was then overlain by a $0.5 \mathrm{~m}$ layer of freshly salvaged peat (obtained from a mixed peatland in the footprint of the mine advance). Surrounding the wetland area, uplands, and upland hills (called hummocks) were also constructed. The uplands were made from tailings sand and constructed with various configurations to test for optimal design to establish a local surface water system, separate from, but inevitably connected to the deeper composite tailings materials residing below.

The 17 ha wetland area was seeded with a myriad of peatland species in year 2011 (Vitt et al. 2016). In year 2012, active pumping of fresh water into the wetland from a nearby lake (Mildred Lake) facilitated 
initial site wetting, however, year 2013 was the first full growing season tracked for research purposes. The underdrain system was used extensively in 2013 largely for testing purposes. In May 2014 underdrain usage ceased and no further management of OSPW has occurred (Nicholls et al. 2016; Spennato et al. 2018). Discharge of near-surface water from the wetland occurs via an outflow system that is turned on to prevent flooding following spring melt and heavy rain events. In general, water moves out of Sandhill Wetland on the east side from the discharge point (East of the weir building) only when pumps are turned on; passive drainage/movement of water out of the wetland is minimal (Twerdy 2019, Thesis).

Fens and marshes background

The experimental Sandhill Watershed was designed to expedite development of a self-sustaining wetland with structural, functional, and chemical attributes, including aspects of water quality, resembling those of regional fens or marshes. In Alberta, four fen sitetypes have been recognized (poor, moderate-rich, extreme-rich, and saline) and all fen types are desirable wetland reclamation outcomes. The chemical composition of surface and groundwater entering fens strongly influences successional trajectory towards a specific type (Environment and Parks 2015). Near-surface groundwater chemistry throughout the OSAA is highly variable, ranging from acidic to basic, and fresh to sodic, thus, all four fen types are present in the region. In brief, poor fens have acidic water with low reduced electrical conductivity (EC) typically less than $100 \mu \mathrm{S} \mathrm{cm}{ }^{-1}$ (Sjörs 1950; Graham et al. 2016; Hartsock et al. 2016), moderate-rich fens have circumneutral water with EC generally less than $250 \mu \mathrm{S} \mathrm{cm}^{-1}$ (Vitt and Chee 1990; Gignac et al. 1991; Locky and Bayley 2010), extreme-rich fens have basic water, with EC ranging from 250 to $450 \mu \mathrm{S} \mathrm{cm}{ }^{-1}$ (Slack et al. 1980; Rochefort and Vitt 1988; Hartsock and Bremer 2018) and saline fens have sodic water with EC ranging from 1000 to $30,000 \mu \mathrm{S} \mathrm{cm}^{-1}$ (Purdy et al. 2005; Stewart and Lemay 2011; Volik et al. 2017). In contrast to fens, the total area occupied by marshes in the OSAA is much smaller, nonetheless, marshes are an acceptable and achievable reclamation outcome (Raab and Bayley 2013). From a functional perspective, decomposition rates typically are higher in marshes compared to fens, resulting in shallower peat deposits or an inability to form peat altogether (Bayley and Mewhort 2004). Marshes can associate with lakes, rivers, or seepage areas and thereby show marked variation in size, water table depth, emergent vegetation structure, and water chemistry characteristics. Near-surface water in marshes typically exhibits circumneutral to slightly basic $\mathrm{pH}$ levels, however, in terms of overall salinity, marshes can be fresh or slightly brackish (Bayley and Mewhort 2004; ESRD 2015). In some cases, marshes may exhibit elevated dissolved sodium concentrations (Purdy et al. 2005; Trites and Bayley 2009).

In total, twelve mature reference wetlands were monitored for making comparisons to Sandhill Wetland. When possible, multiple wetlands of the same type were monitored to better capture extant natural variation in the region. The reference sites included 3 poor fens, 1 open moderate-rich fen, 2 wooded moderate-rich fens, 1 extreme-rich fen, 3 saline fens, 1 fresh marsh, and 1 slightly brackish marsh. Of note, the naming system for reference fens was adopted from historic peatland characterization studies occurring in Alberta (Slack et al. 1980; Vitt and Chee 1990; Purdy et al. 2005). For marshes, sites were categorized using surface water salinity delineations from the Alberta Wetland Classification System (ESRD 2015). The reference wetlands are located along highways 881 and 63, the Clearwater River, and within Elk Island National Park (Table 1).

Water collections

\section{Sandhill Wetland water collection}

Annual water quality sampling has been carried out at Sandhill Wetland during ice-free months. Prior to site commissioning, in years 2009, 2011, and 2012, water was collected intermittently (May-September) from a subset of groundwater wells installed across the watershed area $(n=15,6$, and 14, for years 2009 , 2011, and 2012, respectively). Groundwater samples were pulled at depths ranging from 1.5 to $39.3 \mathrm{~m}$ below the soil surface with a mean sampling depth of $12.4 \mathrm{~m}$. Collection of water from groundwater wells ceased after year 2012.

Annual water quality sampling of near-surface water began in 2013. For years 2013-2017, nearsurface outflow water samples were obtained from the eastern boundary of the site where the collective study 
Table 1 Wetland site locations and elevation

\begin{tabular}{|c|c|c|c|}
\hline Site name & Wetland type & Location & Elevation (meters) \\
\hline SHW & Reclamation wetland & $\begin{array}{l}57^{\circ} 02^{\prime} 25.32^{\prime \prime} \mathrm{N} \\
111^{\circ} 35^{\prime} 22.61^{\prime \prime} \mathrm{W}\end{array}$ & 311 \\
\hline PF1 & Poor fen & $\begin{array}{l}56^{\circ} 22^{\prime} 35.21^{\prime \prime} \mathrm{N} \\
111^{\circ} 14^{\prime} 09.82^{\prime \prime} \mathrm{W}\end{array}$ & 743 \\
\hline PF2 & Poor fen & $\begin{array}{l}55^{\circ} 53^{\prime} 50.14^{\prime \prime} \mathrm{N} \\
112^{\circ} 05^{\prime} 38.15^{\prime \prime} \mathrm{W}\end{array}$ & 695 \\
\hline PF3 & Poor fen & $\begin{array}{l}55^{\circ} 32^{\prime} 17.78^{\prime \prime} \mathrm{N} \\
112^{\circ} 20^{\prime} 09.48^{\prime \prime} \mathrm{W}\end{array}$ & 727 \\
\hline MRF1 & Open moderate-rich fen & $\begin{array}{l}54^{\circ} 28^{\prime} 28.93^{\prime \prime} \mathrm{N} \\
113^{\circ} 19^{\prime} 27.80^{\prime \prime} \mathrm{W}\end{array}$ & 669 \\
\hline MRF2 & Wooded moderate-rich fen & $\begin{array}{l}55^{\circ} 40^{\prime} 25.85^{\prime \prime} \mathrm{N} \\
110^{\circ} 53^{\prime} 35.45^{\prime \prime} \mathrm{W}\end{array}$ & 565 \\
\hline MRF3 & Wooded moderate-rich fen & $\begin{array}{l}55^{\circ} 14^{\prime} 56.96^{\prime \prime} \mathrm{N} \\
111^{\circ} 19^{\prime} 42.70^{\prime \prime} \mathrm{W}\end{array}$ & 569 \\
\hline ERF & Extreme-rich fen & $\begin{array}{l}56^{\circ} 56^{\prime} 56.52^{\prime \prime} \mathrm{N} \\
111^{\circ} 31^{\prime} 41.05^{\prime \prime} \mathrm{W}\end{array}$ & 314 \\
\hline Mf & Fresh marsh & $\begin{array}{l}53^{\circ} 39^{\prime} 35.05^{\prime \prime} \mathrm{N} \\
112^{\circ} 50^{\prime} 54.24^{\prime \prime} \mathrm{W}\end{array}$ & 720 \\
\hline $\mathrm{Mb}$ & Slightly brackish marsh & $\begin{array}{l}53^{\circ} 31^{\prime} 25.40^{\prime \prime} \mathrm{N} \\
112^{\circ} 56^{\prime} 15.93^{\prime \prime} \mathrm{W}\end{array}$ & 726 \\
\hline SAL1 & Saline fen & $\begin{array}{l}56^{\circ} 40^{\prime} 45.25^{\prime \prime} \mathrm{N} \\
111^{\circ} 09^{\prime} 19.72^{\prime \prime} \mathrm{W}\end{array}$ & 255 \\
\hline SAL2 & Saline fen & $\begin{array}{l}56^{\circ} 34^{\prime} 24.97^{\prime \prime} \mathrm{N} \\
111^{\circ} 16^{\prime} 34.14^{\prime \prime} \mathrm{W}\end{array}$ & 398 \\
\hline SAL3 & Saline fen & $\begin{array}{l}53^{\circ} 31^{\prime} 21.38^{\prime \prime} \mathrm{N} \\
112^{\circ} 56^{\prime} 05.73^{\prime \prime} \mathrm{W}\end{array}$ & 729 \\
\hline
\end{tabular}

SHW Sandhill Wetland, $P F$ poor fen, $M R F$ moderaterich fen, $E R F$ extreme-rich fen, $M f$ fresh marsh, $M b$ slightly brackish marsh, $S A L$ saline fen from the outlet and from areas in proximity to the three boardwalks located in the central wetland area $(n=20)$. For year 2019, water was collected exclusively from areas near the three boardwalks $(n=5)$. Characterization of organic compounds in water was completed in year 2019 only. All water samples were analyzed by accredited commercial laboratories EXOVA Canada, Inc. (2009-2017) and later MAXXAM Analytics, Inc. (2018-2019). Protocols and methods used by these labs are shown in supplementary Tables S1 and S2.

\section{Reference site water collection}

At reference sites, in 2018 and 2019 near-surface water samples were collected once per year from 2 to 4 random locations along transects established through the interior of each wetland (except for SAL1 that was 
sampled in 2018 only). In 2018 water sampling was done in the last weeks of June, and in 2019 water collections occurred in the last weeks of July. At reference sites water samples were collected by hand. At sites where water table position was slightly below the ground layer vegetation, a small soil core was removed with an aluminum soil corer, allowed to fill with porewater, thereby allowing water to be collected. Characterization of organic compounds in water was completed in year 2019 only. Water samples from natural sites (2018 and 2019) were analyzed by MAXXAM Analytics, Inc.

\section{Data analysis}

Due to clear violation of analysis of variance (ANOVA) assumptions, namely, non-random sampling conducted at Sandhill Wetland, we were unable to use ANOVA for comparing differences between years at the reclamation site, and further, differences between Sandhill Wetland and reference sites. Using descriptive statistics, we present means \pm standard deviations for all substances/properties measured. For reference wetlands, we lumped observations from wetlands of the same type, thus, we present means \pm standard deviations for a saline fen group $(n=15)$, a moderate-rich fen group $(\mathrm{n}=19)$, an extreme-rich fen group $(n=7)$, a poor fen group $(n=15)$, a slightly brackish marsh group $(\mathrm{n}=5)$, and a fresh marsh group $(\mathrm{n}=6)$.

This study compared water chemistry results to the Environmental Quality Guidelines for Alberta Surface Waters, which are published and updated by Alberta Environment and Parks (AEP). As stated in the guidelines, the purpose is to provide science-based recommendations that protect water uses and form a cornerstone of aquatic ecosystem management and protection. They are foundational elements in cumulative effects management (Government of Alberta 2018). The guideline document includes guidelines for surface water quality (to protect aquatic life, agricultural, and recreational uses). This study used the guidelines for protection of aquatic life only. We report any incidence where a long-term (chronic) or short-term (acute) exceedance was observed in at least one water sample for a given year. Long-term guidelines represent levels of a substance or condition that should result in negligible risk of adverse effects on growth, reproduction, or survival of aquatic biota for an indefinite period. Short-term guidelines are derived from severe effects data and are meant to provide guidance on severe, but transient situations.

\section{Results and discussion}

Sandhill Wetland sub-surface water summary

Collection of water from groundwater wells during years 2009-2012 provided insight on sub-surface water quality prior to reclamation. The groundwater well data represents the OSPW type water associated with in-pit composite tailings porewater. For EC observations, values ranged from 2500 to $5290 \mu \mathrm{S} \mathrm{cm}^{-1}$ with a mean EC of $4213 \mu \mathrm{S} \mathrm{cm} \mathrm{cm}^{-1}$. Sodium was the dominant cation, exhibiting concentrations ranging from 307 to $1370 \mathrm{mg} \mathrm{L}^{-1}$. Due to OSPW influence in deeper wells, sodium concentrations were markedly higher than near-surface water observations. Dissolved calcium and magnesium concentrations in sub-surface water were lower than near-surface water, whereas sub-surface potassium was slightly higher than near-surface water by a small margin (Fig. 2; Table 2). Dissolved bicarbonate and chloride were dominant anions, exhibiting ranges of 548-1720 and 36-1180 $\mathrm{mg} \mathrm{L}^{-1}$, respectively. Sulfate concentrations generally were twofold lower than bicarbonate and chloride, except in year 2012 when concentrations were similar between the three dominant anions (Fig. 3). All organic compounds measured from groundwater wells were below detection limits (Table 3).

Sandhill Wetland sub-surface water quality assessment

The Sandhill Wetland reclamation design concept is based on natural regional analogues, whereby deeper groundwater (the basal aquifer and Devonian waters) displays poorer water quality compared to surface water systems (Devito et al. 2012; Volik et al. 2017). The following substances/properties from groundwater wells exceeded long-term guideline concentrations in at least one sample for a given year: Total alkalinity, ammonium, sulfate, chloride, iron, boron, aluminum, cobalt, molybdenum, silver, arsenic, thallium, and zinc. For iron, thallium, silver, zinc, and aluminum exceedances were infrequent, occurring in less than 


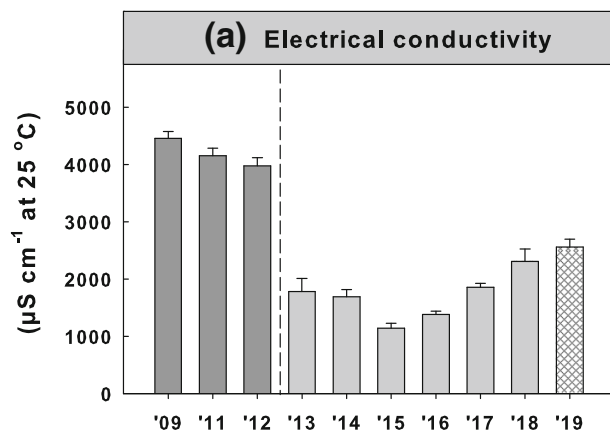

LEGEND
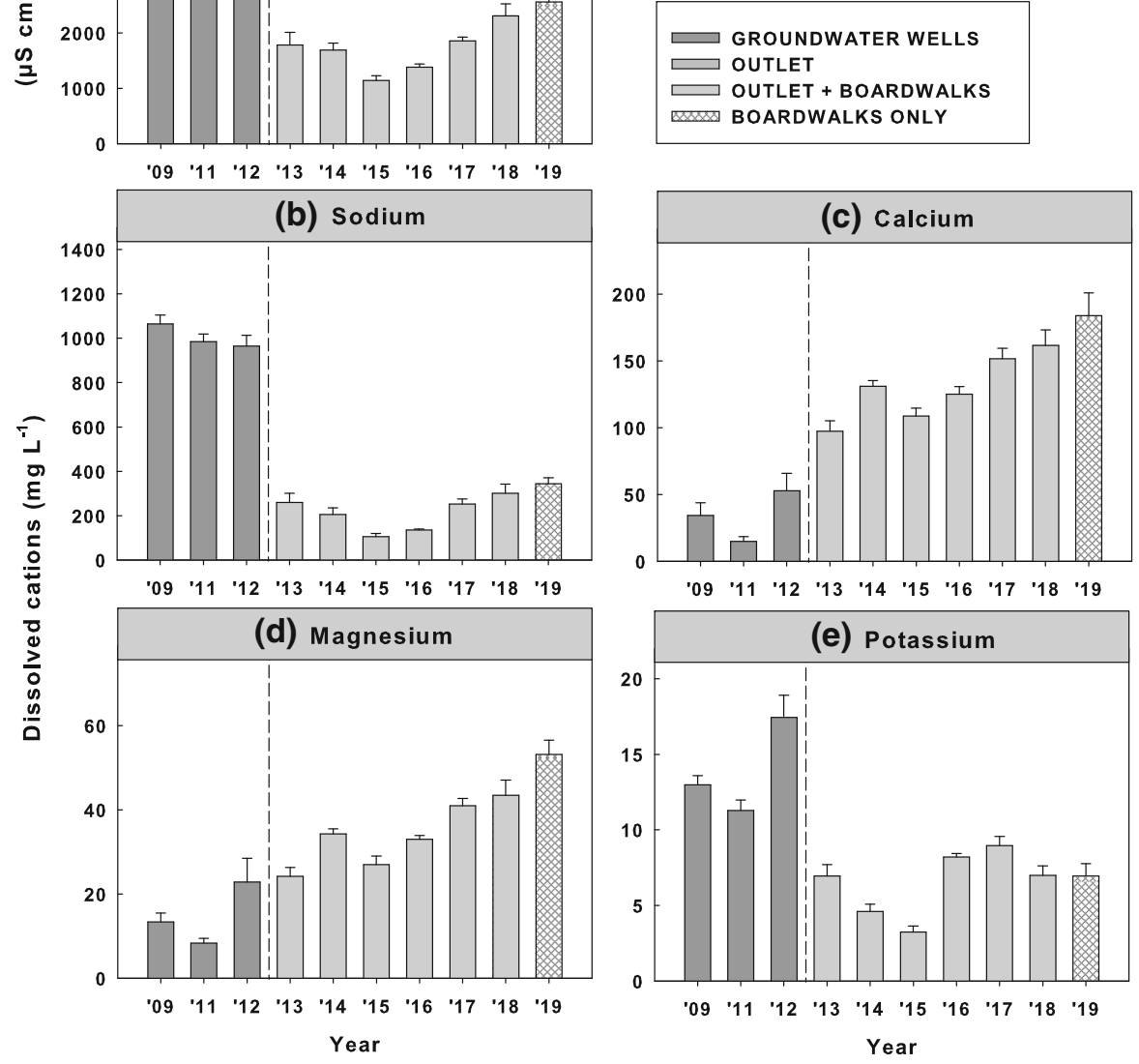

indicates the completion of site construction, and the switch from annual sub-surface water quality monitoring to nearsurface water quality monitoring

Sandhill Wetland near-surface water summary

Due to mixing of freshwater being pumped into the wetland and sub-surface porewater being pulled from the underdrain system into the sump, EC levels of water collected at the outlet in years 2013-2014 were elevated due to OSPW influence (Fig. 2; Table 2). Suspending underdrain usage and closing of the underdrain valve in May 2014 resulted in marked EC decreases at the outlet in year 2015. However, EC levels have increased annually since 2015 in a linear fashion by about $283 \mu \mathrm{S} \mathrm{cm}{ }^{-1}$ to current levels of $2560 \mu \mathrm{S} \mathrm{cm}^{-1}$ measured in 2019. 


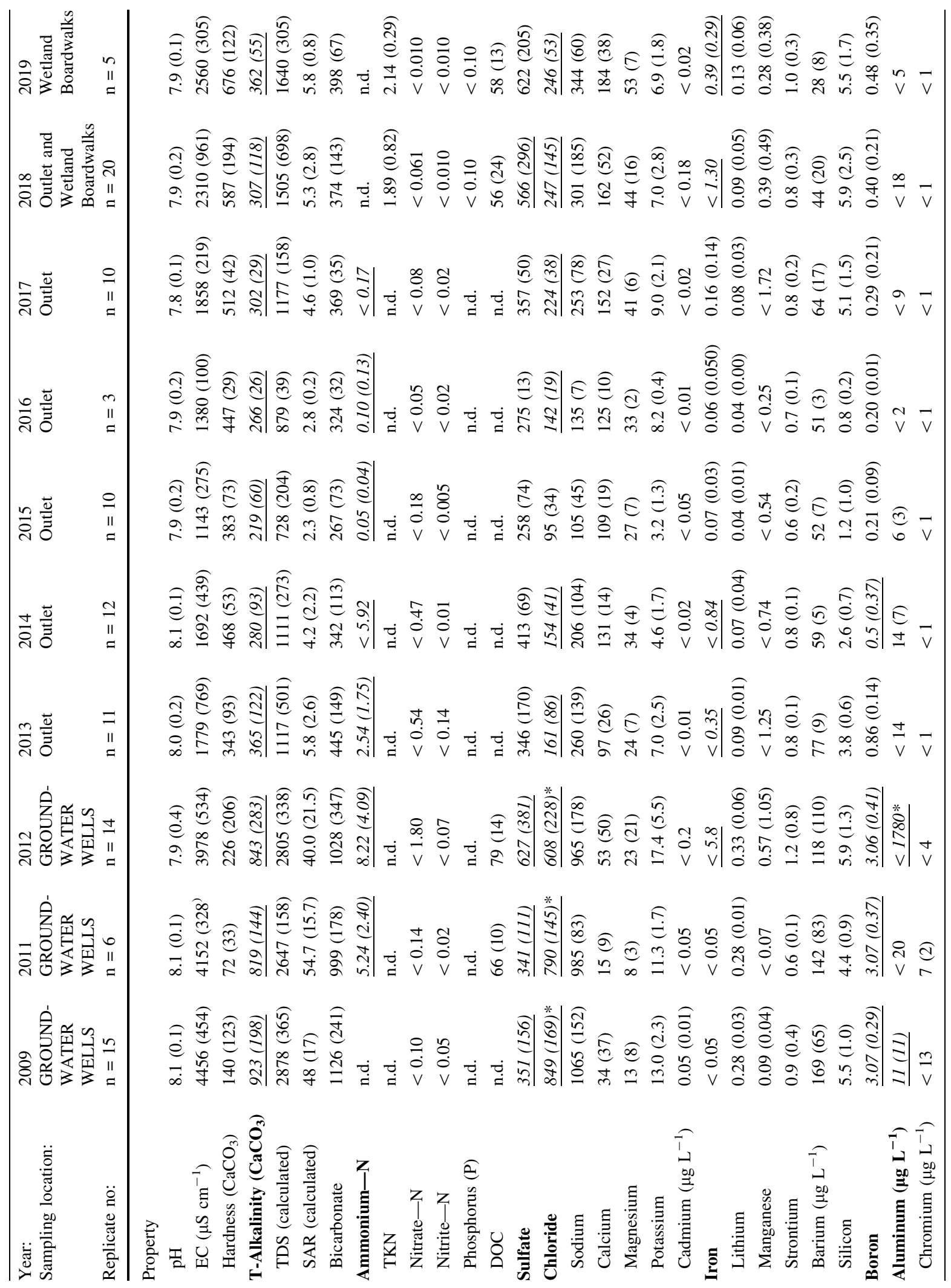




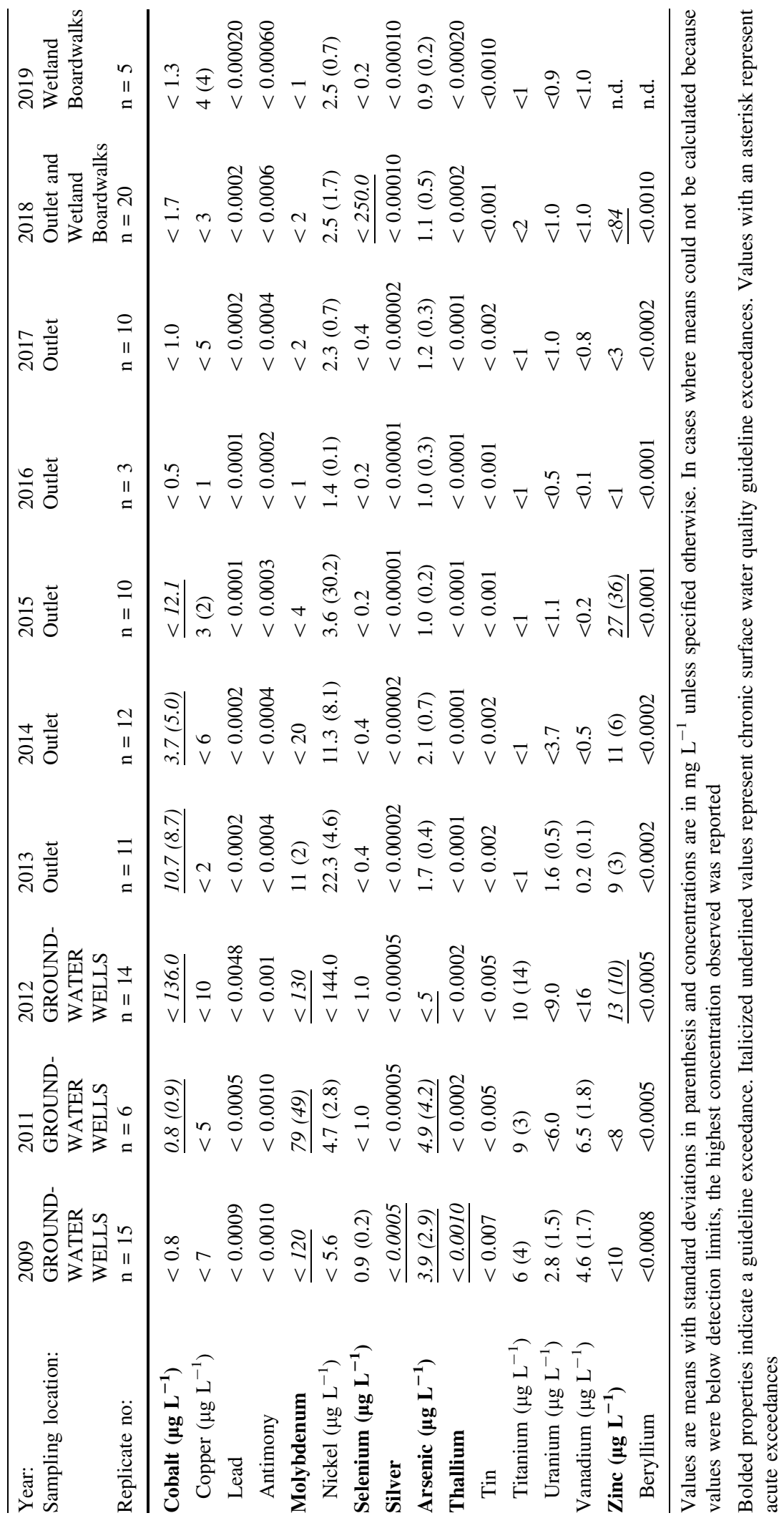




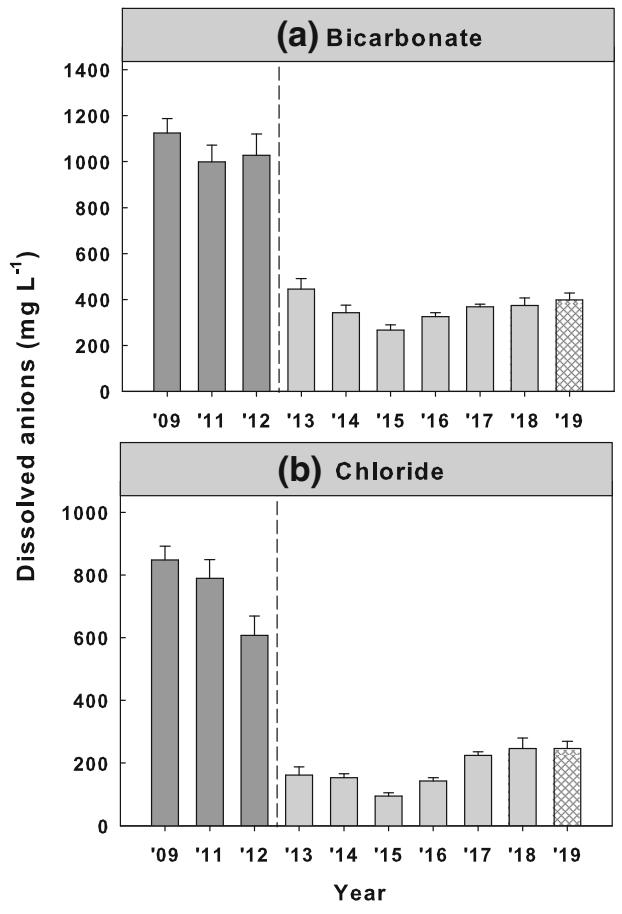

Fig. 3 Bar plots of dissolved anions in sub- and near-surface water at Sandhill Wetland (years 2009-2019). Error bars are standard errors. The dotted line indicates the completion of site

For dissolved base cations, sodium has been dominant each year of monitoring. Similar to EC patterns, elevated sodium concentrations at the outlet in years 2013 and 2014 (means: 260 and $206 \mathrm{mg} \mathrm{L}^{-1}$, respectively) was due to mixing of underdrain water and near-surface water. Sodium concentrations dropped precipitously at the outlet in year 2015 (mean: $105 \mathrm{mg} \mathrm{L}^{-1}$ ) following closure of the underdrain system. Excluding samples collected in 2013 and 2014, sodium concentrations have increased annually by about $48 \mathrm{mg} \mathrm{L}^{-1}$ to current levels of $344 \mathrm{mg} \mathrm{L}^{-1}$ in year 2019. Adverse physiologic effects from prolonged sodium exposure may affect some wetland plants that initially established in an environment less concentrated with sodium. Over subsequent years, replacement of sodium-sensitive species by halophytic species may occur at Sandhill Wetland, warranting further monitoring of both water chemistry and plant community composition to capture these important successional changes (Glaeser et al. 2016). The divalent cation calcium historically has been the second most abundant cation in near-surface water, followed by magnesium. Calcium and magnesium concentrations in near-surface water exceeded

\section{LEGEND}

GROUNDWATER WELLS

$\square$ OUTLET ONLY

$\square$ OUTLET + BOARDWALKS

BOARDWALKS ONLY

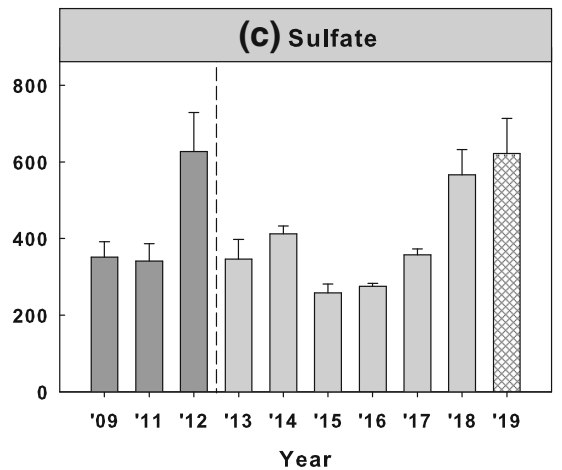

construction, and the switch from annual sub-surface water quality monitoring to near-surface water quality monitoring

concentrations in sub-surface water. Using stable isotopes, both Biagi et al. (2019) and Vessey et al. (2019) showed annual increases in calcium and magnesium concentrations are in part due to cation exchange reactions, whereby upward movement of sodium-rich OSPW has displaced much of the calcium and magnesium previously adsorbed to the mineral clay and placed peat soil layers. Additional calcium and magnesium contents may be entering Sandhill Wetland via dust deposition and surface runoff (Wieder et al. 2016b). For years 2014 and 2015 specifically, other studies that measured calcium and magnesium across the spatial extent of Sandhill Wetland reported higher values than our observations from the outlet (Vitt et al. 2016; Biagi et al. 2019). Thus, calcium and magnesium concentrations are likely spatially variable. In contrast to sodium, calcium, and magnesium, dissolved potassium concentrations have remained quite static by comparison; perhaps serving as a limiting nutrient for plant growth.

Sulfate and bicarbonate were both dominant anions in near-surface water over the first five years (Fig. 3; Table 2). However, in years 2018-2019 sulfate concentrations markedly increased to surpass 
Table 3 Organic compounds measured at Sandhill Wetland and reference wetlands

\begin{tabular}{|c|c|c|}
\hline Compound & Long-term guideline (Chronic) $\left(\mu \mathrm{g} \mathrm{L}^{-1}\right)$ & Minimum detection limit $\left(\mu \mathrm{g} \mathrm{L}^{-1}\right)$ \\
\hline F1 (C6-C10) & 150 & $<100$ \\
\hline Benzene & 40 & $<0.40$ \\
\hline $\mathrm{m} \& \mathrm{p}$-Xylene & & $<0.80$ \\
\hline Toluene & 0.5 & $<0.40$ \\
\hline Ethylbenzene & & $<0.40$ \\
\hline o-Xylene & & $<0.40$ \\
\hline F1 (C6-C10)-BTEX & 150 & $<100$ \\
\hline Xylenes (Total) & 30 & $<0.89$ \\
\hline B[a]P TPE Total Potency Equivalents & & $<0.010$ \\
\hline Quinoline & 3.4 & $<0.20$ \\
\hline Naphthalene & 1.0 & $<0.10$ \\
\hline Chrysene & & $<0.0085$ \\
\hline Benzo(k)fluoranthene & & $<0.0085$ \\
\hline Benzo(e)pyrene & & $<0.050$ \\
\hline Benzo(a)pyrene & 0.015 & $<0.0075$ \\
\hline Pyrene & & $<0.020$ \\
\hline Perylene & & $<0.050$ \\
\hline Acenaphthylene & 5.8 & $<0.10$ \\
\hline Indeno(1,2,3-cd)pyrene & & $<0.0085$ \\
\hline Dibenz(a,h)anthracene & & $<0.0075$ \\
\hline 2-Methylnaphthalene & & $<0.10$ \\
\hline Acenaphthene & & $<0.10$ \\
\hline Fluorene & 3.0 & $<0.050$ \\
\hline 1-Methylnaphthalene & & $<0.10$ \\
\hline Benzo(a)anthracene & & $<0.0085$ \\
\hline Phenanthrene & & $<0.050$ \\
\hline Anthracene & & $<0.010$ \\
\hline Benzo(c)phenanthrene & & $<0.050$ \\
\hline Fluoranthene & & $<0.010$ \\
\hline Benzo(g,h,i)perylene & & $<0.0085$ \\
\hline Benzo(b\&j)fluoranthene & & $<0.0085$ \\
\hline Acridine & 4.4 & $<0.040$ \\
\hline
\end{tabular}

bicarbonate. It is possible sulfate concentrations are spatially variable across the wetland area, which is supported by findings from Biagi et al. (2019). Thus, elevated sulfate concentrations observed in years 2018 and 2019 are potentially due to sampling additional areas beyond the outlet location. Elevated sulfate concentrations in water have been hypothesized to constrain the production of both methylmercury and methane at the site (Oswald and Carey 2016; Clark et al. 2019, respectively), therefore our sulfate water quality data findings potentially explain and support previously reported observations of low methylmercury and methane production at Sandhill Wetland compared to natural reference sites. For the anion chloride, although concentrations were lower than sulfate and bicarbonate, chloride concentrations have exceeded those of calcium most years. Since year 2015, chloride, bicarbonate, and sulfate, concentrations have increased on average by 30,26 , and $73 \mathrm{mg} \mathrm{L}^{-1}$ each year to current levels of 246,398 , and 
$622 \mathrm{mg} \mathrm{L}^{-1}$, respectively in 2019. Overall, with few exceptions we demonstrate the dominant anions and cations present in near-surface water have increased annually in a linear fashion since year 2015 (Figs. 2 and 3). These patterns by dominant ions cumulatively are responsible for annual increases in EC, total alkalinity, total hardness, and total dissolved solids (Table 2).

Similar to anion and cation patterns, closure of the underdrain system in year 2014 resulted in marked decreases in ammonium concentrations at the outlet (Table 2). From 2015 to 2019 dissolved inorganic nitrogen and phosphorus concentrations were less than $1.0 \mathrm{mg} \mathrm{L}^{-1}$ in all years monitored. Further, for all organic compounds measured in near-surface water, concentrations were below detection limits in all years (Table 3); an important discovery as many of the substances evaluated are harmful to biota (e.g., insects and birds) at low concentrations (Barr 2009; Gentes et al. 2006; Foote 2012).

Sandhill Wetland near-surface water quality assessment

Comparing the near-surface water quality at Sandhill Wetland to the Environmental Quality Guidelines for Alberta Surface Waters for protection of aquatic life produced fewer exceedances than groundwater well samples. Moreover, in most cases near-surface water exceedances were less severe. The following substances/properties in near-surface water exceeded a long-term guideline recommendation: Total alkalinity, ammonium, sulfate, chloride, iron, boron, cobalt, selenium, and zinc (Government of Alberta 2018). Near-surface total alkalinity exceeded guidelines in all years; yet, values generally were threefold lower than sub-surface water (sub-surface T-alkalinity as $\mathrm{CaCO}_{3}$ mean: about 860). While ammonium exceedances were detected in all years monitored, ammonium concentrations post year 2014 (following closure of the underdrain system) are approaching recommended levels (recommended guideline values for Sandhill Wetland ambient conditions $=0.41-1.91 \mathrm{mg} \mathrm{L}^{-1}$; varies with $\mathrm{pH}$ and temperature). In fact, ammonium concentrations currently are within the ranges of other regional peatland systems (Graham et al. 2016; Hartsock et al. 2016, 2019). Excluding a single cobalt exceedance in year 2015 of $12.1 \mu \mathrm{g} \mathrm{L}^{-1}$, cobalt and boron exceedances occurred only while the underdrain system was in use, suggesting exceedances were likely due to mixing of sub-surface and near-surface water at the outlet. Zinc and selenium exceedances were detected in four and one water sample, respectively, out of a total of 71 near-surface water samples. The heavy metal iron exceeded guideline recommendations in ten samples total out of 71. Dissolved chloride has exceeded guideline recommendations in all years except 2015, and chloride concentrations have continued to increase annually. For dissolved sulfate, guideline exceedances occurred only in 2018. Because sulfate guidelines are influenced by ambient hardness levels, amelioration of sulfate exceedances at Sandhill Wetland are due to concurrent increases in water hardness. Recommend EC and sodium concentrations are absent from the Environmental Quality Guidelines for Alberta Surface Waters for protection of aquatic life, however, EC and sodium has increased annually in near-surface water since 2015 (SHW 2019 EC and $\mathrm{Na}^{+}$means: $2560 \mu \mathrm{S} \mathrm{cm}^{-1}$ and $344 \mathrm{mg} \mathrm{L}^{-1}$, respectively) and measured levels are higher than most reference wetlands; except for the saline fens where EC and sodium concentrations were about $9000 \mu \mathrm{S} \mathrm{cm}^{-1}$ and $2000 \mathrm{mg} \mathrm{L}^{-1}$, respectively.

Sandhill Wetland vs natural wetlands

One of the central questions for the Sandhill Watershed was whether a fen could/would develop with time if the initial conditions were properly established. At the onset, initial conditions most closely mimicked a circumneutral moderate-rich fen based on site wetting with fresh lake water and a seed mix composition comprised of $\sim 80 \%$ Carex aquatilis seeds (Vitt et al. 2016). Because the placed peat layer contained some material from an acidic Sphagnum-dominated poor fen, however, and due to anticipated interactions with OSPW, there was potential for Sandhill Wetland to develop into a variety of different wetland site types. Several reference wetlands spanning a gradient of potential successional endpoints were therefore selected for comparison against Sandhill Wetland, and for evaluating whether the site has been functioning equivalent to any type of natural site monitored. From a water chemistry standpoint, based on dominant ions present (e.g., sodium, calcium, magnesium, bicarbonate, chloride, and sulfate) and other properties (e.g., total alkalinity, total hardness, EC, pH and potassium), water chemistry at Sandhill Wetland has 
Table 4 Porewater concentrations among reference wetlands

\begin{tabular}{|c|c|c|c|c|c|c|}
\hline $\begin{array}{l}\text { Wetland type: } \\
\text { Replicate no: }\end{array}$ & $\begin{array}{l}M b \\
n=5\end{array}$ & $\begin{array}{l}\text { Mf } \\
n=6\end{array}$ & $\begin{array}{l}\text { SAL } \\
n=15\end{array}$ & $\begin{array}{l}\text { MRF } \\
n=19\end{array}$ & $\begin{array}{l}\text { ERF } \\
n=7\end{array}$ & $\begin{array}{l}\mathrm{PF} \\
\mathrm{n}=15\end{array}$ \\
\hline \multicolumn{7}{|l|}{ Property } \\
\hline pH & $7.78(0.24)$ & $7.12(0.11)$ & $7.40(0.58)$ & $7.06(0.22)$ & $7.92(0.09)$ & $3.99(0.26)$ \\
\hline $\mathrm{EC}\left(\mu \mathrm{S} \mathrm{cm}{ }^{-1}\right)$ & 717 (158) & $216(35)$ & $8808(5930)$ & $134(53)$ & $329(69)$ & $38(68)$ \\
\hline Hardness $\left(\mathrm{CaCO}_{3}\right)$ & $226(55)$ & $110(23)$ & $615(528)$ & $69(23)$ & $194(10)$ & $5(4)$ \\
\hline T-Alkalinity & $504(157)$ & $90(16)$ & $496(415)$ & $62(23)$ & $180(24)$ & $<1$ \\
\hline TDS (calculated) & $562(145)$ & $130(28)$ & $6323(4514)$ & $71(25)$ & $227(20)$ & $32(34)$ \\
\hline SAR (calculated) & $4.15(0.66)$ & $0.43(0.05)$ & $37.13(9.03)$ & $0.21(0.10)$ & $0.65(0.03)$ & $0.36(0.43)$ \\
\hline Bicarbonate & $616(188)$ & $111(21)$ & $613(513)$ & 77 (29) & $220(31)$ & $<1$ \\
\hline Ammonium-N & $0.11(0.07)$ & $0.11(0.08)$ & $0.40(0.37)$ & $0.05(0.03)$ & $0.06(0.03)$ & $0.04(0.03)$ \\
\hline TKN & $3.50(0.63)$ & $3.63(1.26)$ & $5.65(3.95)$ & $0.95(0.50)$ & $0.77(0.24)$ & $0.98(0.42)$ \\
\hline Nitrate- $\mathbf{N}$ & $\leq 3.4$ & $<0.20$ & $<0.26$ & $<1.20$ & $<0.17$ & $<2.20$ \\
\hline Nitrite- $-\mathrm{N}$ & $0.26(0.33)$ & $<0.20$ & $<0.18$ & $<0.20$ & $<0.010$ & $<0.010$ \\
\hline Phosphorus & $0.59(0.48)$ & $0.84(0.41)$ & $0.04(0.03)$ & $0.01(0.00)$ & $<0.01$ & $0.11(0.11)$ \\
\hline DOC & $62(14)$ & $72(26)$ & $63(38)$ & $26(7)$ & $17(2)$ & $32(9)$ \\
\hline Sulfate & $616(188)$ & $111(21)$ & $613(513)$ & 77 (29) & $220(31)$ & $<1$ \\
\hline Chloride & $8(5)$ & $4(1)$ & $3245(3112)^{*}$ & $3(2)$ & $16(5)$ & $5(11)$ \\
\hline Sodium & $144(38)$ & $10(2)$ & 1979 (1372) & $4(2)$ & $22(2)$ & $2(4)$ \\
\hline Calcium & $59(16)$ & $27(6)$ & $144(120)$ & $16(6)$ & $53(4)$ & $1(1)$ \\
\hline Magnesium & $19(4)$ & $10(2)$ & $62(56)$ & $7(2)$ & $15(1)$ & $<2$ \\
\hline Potassium & $4.9(2.9)$ & $4.9(5.2)$ & $2.9(1.9)$ & $1.3(1.3)$ & $1.9(0.8)$ & $0.7(0.4)$ \\
\hline Cadmium $\left(\mu \mathrm{g} \mathrm{L}^{-1}\right)$ & $<0.020$ & $<0.020$ & $<0.040$ & $\leq 0.15$ & $<0.15$ & $\leq 0.18^{*}$ \\
\hline Iron & $0.93(0.95)$ & $3.15(2.01)$ & $\leq 85$ & $\leq 0.32$ & $<0.068$ & $\leq 1.1$ \\
\hline Lithium & $0.06(0.02)$ & $<0.04$ & $<0.48$ & $<0.020$ & $<0.020$ & $<0.020$ \\
\hline Manganese & $3.18(2.34)$ & $1.33(1.11)$ & $<2.20$ & $<2.60$ & $<1.80$ & $0.059(0.061)$ \\
\hline Strontium & $0.35(0.08)$ & $0.23(0.05)$ & $4.89(5.16)$ & $<0.14$ & $0.10(0.01)$ & $<0.023$ \\
\hline Barium & $0.12(0.07)$ & $0.04(0.02)$ & $<0.60$ & $<0.076$ & $0.05(0.01)$ & $<0.18$ \\
\hline Silicon & $12.48(4.23)$ & $3.05(1.28)$ & $9.15(6.49)$ & $3.38(0.83)$ & $3.00(1.58)$ & $<3.90$ \\
\hline Boron & $0.07(0.01)$ & $0.05(0.01)$ & $0.51(0.17)$ & $<0.020$ & $0.04(0.01)$ & $<0.10$ \\
\hline Aluminum $\left(\mu \mathrm{g} \mathrm{L}^{-1}\right)$ & $6.0(2.0)$ & $24.0(15.0)$ & $30.0(33.0) *$ & $<11.0$ & $<6.8$ & $70.0(47.0)^{*}$ \\
\hline Chromium & $<0.0010$ & $<0.0010$ & $<0.0020$ & $<0.012$ & $<0.0010$ & $<0.013$ \\
\hline Cobalt $\left(\mu \mathrm{g} \mathrm{L}^{-1}\right)$ & $\leq 2.2$ & $\leq 3.1$ & $<1.3$ & $<0.4$ & $<0.3$ & $\leq 1.5$ \\
\hline Copper $\left(\mu \mathrm{g} \mathrm{L}^{-1}\right)$ & $<0.23$ & $<0.24$ & $<1.6$ & $<3.5$ & $<1.2$ & $\overline{<78^{*}}$ \\
\hline Lead & $<0.00020$ & $<0.00020$ & $<0.00069$ & $<0.00035$ & $<0.00020$ & $<0.00020$ \\
\hline Antimony & $<0.00060$ & $<0.00060$ & $<0.0087$ & $<0.00060$ & $<0.00060$ & $<0.00060$ \\
\hline Molybdenum $\left(\mu \mathrm{g} \mathrm{L}^{-1}\right)$ & $<0.81$ & $<0.20$ & $<0.40$ & $<0.20$ & $<0.20$ & $<0.20$ \\
\hline Nickel $\left(\mu \mathrm{g} \mathbf{L}^{-1}\right)$ & $1.9(0.9)$ & $2.2(0.8)$ & $<2.7$ & $<0.8$ & $<2.3$ & $<2.6^{*}$ \\
\hline Selenium $\left(\mu g \mathrm{~L}^{-1}\right)$ & $<0.44$ & $<0.20$ & $\leq 7.6$ & $<0.20$ & $<0.20$ & $<0.20$ \\
\hline Silver & $<0.00010$ & $<0.00010$ & $<0.00020$ & $<0.00010$ & $<0.00010$ & $<0.00010$ \\
\hline $\operatorname{Arsenic}\left(\mu \mathrm{g} \mathrm{L}^{-1}\right)$ & $1.4(0.7)$ & $1.0(0.2)$ & $0.7(0.3)$ & $1.5(2.2)$ & $<0.67$ & $\leq 10.0$ \\
\hline Thallium & $<0.00020$ & $<0.00020$ & $<0.00040$ & $<0.00020$ & $<0.00020$ & $<0.00020$ \\
\hline Tin & $<0.0010$ & $<0.0010$ & $<0.0020$ & $<0.0010$ & $<0.0022$ & $<0.002$ \\
\hline Titanium & $<0.0010$ & $<0.0010$ & $<0.0035$ & $<0.015$ & $<0.0010$ & $<0.016$ \\
\hline Uranium & $<0.0017$ & $<0.00010$ & $<0.00020$ & $<0.00010$ & $<0.00010$ & $<0.00010$ \\
\hline Vanadium & $<0.0010$ & $<0.0010$ & $<0.0020$ & $<0.018$ & $<0.0010$ & $<0.018$ \\
\hline
\end{tabular}


Table 4 continued

\begin{tabular}{lllllll}
\hline $\begin{array}{l}\text { Wetland type: } \\
\text { Replicate no: }\end{array}$ & $\begin{array}{l}\text { Mb } \\
\mathrm{n}=5\end{array}$ & $\begin{array}{l}\text { Mf } \\
\mathrm{n}=6\end{array}$ & $\begin{array}{l}\mathrm{SAL} \\
\mathrm{n}=15\end{array}$ & $\begin{array}{l}\text { MRF } \\
\mathrm{n}=19\end{array}$ & $\begin{array}{l}\text { ERF } \\
\mathrm{n}=7\end{array}$ & $\begin{array}{l}\text { PF } \\
\mathrm{n}=15\end{array}$ \\
\hline Zinc $\left(\boldsymbol{\mu \mathbf { g ~ L } ^ { - 1 }}\right)$ & $<9.1$ & $<3.0$ & $<18.0$ & $<9.9$ & $<7.5$ & $\underline{11.1(5.8)}$ \\
Beryllium & $<0.0010$ & $<0.0010$ & $<0.0020$ & $<0.0010$ & $<0.0010$ & $<0.0010$ \\
\hline
\end{tabular}

Values are means with standard deviations in parenthesis. In cases where means could not be calculated b/c values were below detection limit, the highest concentration observed was reported

Bolded properties indicate a guideline exceedance

Italicized underline values represent chronic surface water quality guideline exceedances. Values with an asterisk represent acute exceedances. $M b$ slightly brackish marsh, $M f$ fresh marsh, $S A L$ saline fen, $M R F$ moderate-rich fen, $E R F$ extreme-rich fen, $P F$ poor fen

clearly shared the most chemical range overlap with the slightly brackish marsh and saline fen reference sites (Tables 2 and 4). Because anion and cation concentrations have increased annually at Sandhill Wetland, water chemistry is becoming increasingly similar to saline fens with each passing year. The site overall has exhibited few likenesses with water chemistry at the other freshwater reference sites.

\section{Reference site water quality assessment}

Compared to the Environmental Quality Guidelines for Alberta Surface Waters for protection of aquatic life there were several instances of exceedances at natural sites (Table 4). The poor fens exceeded guidelines most frequently. Substances exceeding guideline recommendations at the poor fens included $\mathrm{pH}$, cadmium, iron, aluminum, cobalt, copper, nickel, arsenic, zinc, and toluene (toluene exceedance $=1.30 \mu \mathrm{g} \mathrm{L}^{-1}$ ). Because recommended guideline values for select substances change considerably based on ambient site conditions, levels of a substance deemed problematic at one site may not necessary be harmful at another (Government of Alberta 2018). Due to acidic conditions characteristic of poor fens $(\mathrm{pH} \sim 4.0$ ), recommended guideline concentrations for several substances are lower than circumneutral and alkaline reference sites. The sodic saline fens exceeded guidelines for five properties/ substances that included total alkalinity, chloride, iron, aluminum, and selenium. The slightly brackish marsh exceeded guidelines for six properties/substances that included total alkalinity, nitrate, sulfate, iron, cobalt, and toluene (toluene exceedance $=19.0 \mu \mathrm{g} \mathrm{L}^{-1}$ ). Of these listed substances at the saline fens and slightly brackish marsh, seven were shown to exceed guidelines in near-surface water at Sandhill Wetland (e.g., chloride, total alkalinity, sulfate, iron, cobalt, selenium, and zinc). Further, exceedances for total alkalinity and dissolved iron were detected across five of the six reference wetland site types, thereby suggesting several substances commonly exceed water quality guidelines in regional natural wetlands. Overall, we present fifteen examples of guideline exceedances (five of which were acute exceedances) detected in near-surface water at the natural reference sites. At Sandhill Wetland, groundwater well samples and near-surface water cumulatively exceeded guidelines for fourteen different substances/properties. The Alberta water quality guidelines note exceptions to the application of guidelines where natural water quality does not meet proposed recommendations. Although Sandhill Wetland is not a natural system, near-surface water chemistry at the site is quite representative of saline fens and slightly brackish marshes. Because the reclamation site was designed to assist succession towards a natural wetland analogue, here we provide rationale for establishing site-specific guidelines or objectives for select chemical substances and properties, namely for those that exceeded guidelines at the regional reference sites (e.g., $\mathrm{pH}, \mathrm{T}$-alkalinity, nitrate$\mathrm{N}$, sulfate, chloride, cadmium, iron, aluminum, cobalt, copper, nickel, selenium, arsenic, zinc and toluene).

\section{Conclusions}

We conclude that compared to natural reference wetlands, near-surface water chemistry at Sandhill Wetland was comparable to the slightly brackish marsh and saline fens. However, as anions and cations have increased in the wetland annually, site chemistry 
is becoming increasingly similar to regional saline fen systems. In the most recent year of monitoring (year 2019), near-surface water quality at Sandhill Wetland exceeded Alberta surface water quality guidelines for three substances (dissolved chloride, total alkalinity, and iron). The saline fens also exceeded guidelines for the same substances/properties. The alkaline fen was the only site to exhibit fewer guideline exceedances than Sandhill Wetland in 2019, whereas the poor fens had up to ten exceedances, demonstrating natural environmental factors in the region can certainly account for variations in water quality. Overall, generic government issued guidelines are a good starting point, but site-specific water quality targets should be developed for Sandhill Wetland and future constructed wetlands on tailings substrates. Future studies should more thoroughly investigate water quality of natural wetlands in the OSSA to develop science-driven recommendations for setting exceptions for specific substances at appropriate concentrations, which would benefit water quality interpretations for opportunistic and constructed wetlands on mine sites.

Evaluation of surface water chemistry at Sandhill Wetland indicates freshwater systems should be carefully targeted for tailings deposit reclamation and that suitable conditions exhibited by slightly brackish marshes and saline fens may be likely endpoints. This study also documents that for most substances measured, surface water quality at Sandhill Wetland falls within the range of the results from natural sites, a good indicator of progress towards achieving equivalent wetland function. Water collected from groundwater monitoring wells generally was of poorer quality, and guideline exceedances occurred more frequently. Cumulatively these observations justify continued reclamation designs aimed at developing shallow, fresher, surface water systems that are hydraulically separated from deeper tailings OSPW affected porewater. That said, the measured and inevitable mixing of OSPW with the reclaimed area's initially fresh, meteoric sourced surface waters, has not pushed the system to an undesirable endpoint based on natural reference analogues and studies to date. Investigations should continue to understand long-term performance at Sandhill Wetland as nearsurface water chemistry has yet to stabilize.
Acknowledgements This work was funded by Syncrude Canada Ltd. through grant no. 4600101055 to Dale H. Vitt. We thank the Syncrude Reclamation and Closure team members (Carla Wytrykush, Chris Beierling, Mohamed Salem, John Arnold, Wendy Kline, and Richard Kao) for logistical assistance and support. We thank Derek Tollette, Samantha Kitchen and Brian Widmer for assistance in the field. Special thanks to Phillip Piercey for assisting with off-site work near the Clearwater River. We thank our Elk Island National Park contacts Jonathan Demoor and Annisa Prendergast, who assisted with permit approval and logistics. Lastly, we thank two anonymous reviewers for their constructive comments on a previous version of the manuscript.

Author contributions J.H.-Wrote the manuscript, organized the data, created graphs, and collected water samples. J.P.Collected water samples, provided data, reviewed the manuscript, and provided comments/information regarding history about the study site. M.H.--Assisted with field work, sample collection, and provided several comments on the manuscript. D.V.-Principal investigator of the research project, and provided constructive comments on the manuscript.

Funding This work was funded by Syncrude Canada Ltd. through Grant No. 4600101055 to Dale H. Vitt.

Availability of data and material Data will be made available upon request to the corresponding author.

\section{Compliance with ethical standards}

Conflict of interest Author Jessica Piercey is a Syncrude Canada Ltd. employee.

Consent for publication All authors give consent for the manuscript to be published in its current form.

Open Access This article is licensed under a Creative Commons Attribution 4.0 International License, which permits use, sharing, adaptation, distribution and reproduction in any medium or format, as long as you give appropriate credit to the original author(s) and the source, provide a link to the Creative Commons licence, and indicate if changes were made. The images or other third party material in this article are included in the article's Creative Commons licence, unless indicated otherwise in a credit line to the material. If material is not included in the article's Creative Commons licence and your intended use is not permitted by statutory regulation or exceeds the permitted use, you will need to obtain permission directly from the copyright holder. To view a copy of this licence, visit http://creativecommons.org/licenses/by/4.0/.

\section{References}

Alberta Environment and Sustainable Resource Development (ESRD) (2015) Alberta Wetland classification system. 
Water Policy Branch, Policy and Planning Division, Edmonton, $\mathrm{AB}$

Barr L (2009) Influence of consolidated mine tailings and oil sands process water on colonization potential of aquatic invertebrates of constructed wetlands in the Athabasca oil sands, Alberta. Thesis, University of Windsor, Windsor, Ontario, Canada

Bayley SE, Mewhort RL (2004) Plant community structure and junctional differences between marshes and fens in the southern boreal region of Alberta. Can Wetlands 24:277-294 https://doi.org/10.1672/02775212(2004)024[0277,pcsafd]2.0.co;2

Biagi KM, Oswald CJ, Nicholls EM, Carey SK (2019) Increases in salinity following a shift in hydrologic regime in a constructed wetland watershed in a post-mining oil sands landscape. Sci Total Environ 653:1445-1457. https://doi. org/10.1016/j.scitotenv.2018.10.341

Chalaturnyk RJ, Scott DJ, Ozum B (2002) Management of oil sands tailings. Pet Sci Technol 20:1025-1046. https://doi. org/10.1081/LFT-120003695

Clark MG, Humphreys E, Carey SK (2019) The initial three years of carbon dioxide exchange between the atmosphere and a reclaimed oil sand wetland. Ecol Eng 135:116-126. https://doi.org/10.1016/j.ecoleng.2019.05.016

Devito KJ, Creed IF, Gan T, Mendoza C, Petrone R, Silins U, Smerdon B (2005) A framework for broad-scale classification of hydrologic response units on the Boreal plain: Is topography the last thing to consider? Hydrol Process 19:1705e1714

Devito K, Mendoza C, Qualizza C (2012) Conceptualizing water movement in the boreal plains: implications for watershed reconstruction. Synthesis report prepared for the Canadian Oil Sands Network for Research and Development, Environmental and Reclamation Research Group, p 164

Environment and Parks (2015) Reclamation criteria for wellsites and associated facilities for peatlands. ISBN: 978-14601-2386-7

Foote L (2012) Threshold considerations and wetland reclamation in Alberta's mineable oil sands. Ecol Soc 17(11). https://doi.org/10.5751/es-04673-170135

Gentes ML, Waldner C, Papp Z, Smits JG (2006) Effects of oil sands tailing compounds and harsh weather on mortality rates, growth and detoxification effort in nestling tree swallows (Tachycineta bicolor). Environ Pollut 142:24-33. https://doi.org/10.1016/j.envpol.2005.09.013

Gignac LD, Vitt DH, Zoltai SC, Bayley SE (1991) Bryophyte response surfaces along climatic, chemical, and physical gradients in peatlands of western Canada. Nova Hedwigia 53:27-71

Glaeser LC, Vitt DH, Ebbs SE (2016) Responses of the wetland grass, Beckmannia syzigachne, to salinity and soil wetness: Consequences for wetland reclamation in the oil sands area of Alberta. Can Ecol Eng 86:13-23. https://doi.org/10. 1016/j.ecoleng.2015.10.009

Gorham E (1991) Northern peatlands - role in the carbon-cycle and probable responses to climatic warming. Ecol Appl 1:182-195. https://doi.org/10.2307/1941811

Government of Alberta (2018) Environmental quality guidelines for Alberta surface waters. water policy branch,
Alberta environment and parks. Edmonton, Alberta, Canada

Graham JA, Hartsock JA, Vitt DH, Wieder RK, Gibson JJ (2016) Linkages between spatio-temporal patterns of environmental factors and distribution of plant assemblages across a boreal peatland complex. Boreas 45:207-219

Harris ML (2007) Guideline for wetland establishment on reclaimed oil sands leases, second ed. Reclamation working group Cumulative Environmental Management Association, Fort McMurray, Alberta, Canada, 117

Hartsock JA, Bremer E (2018) Nutrient supply rates in a boreal extreme-rich fen using ion exchange membranes. Ecohydrology 11(8):e1995. https://doi.org/10.1002/eco.1995

Hartsock JA, House M, Vitt DH (2016) Net nitrogen mineralization in boreal fens: a potential performance indicator for peatland reclamation. Botany 94:1027-1040. https://doi. org/10.1139/cjb-2015-0263

Hartsock JA, Bremer E, Vitt DH (2019) Nutrient supply patterns across the Sandhill Fen reclamation watershed and regional reference fens in Alberta, Canada: an ion exchange membrane study. Ecohydrology. https://doi.org/10.1002/eco. 2188

Lee P, Cheng R (2009) Bitumen and biocarbon: Land use conversions and loss of biological carbon due to bitumen operations in the Boreal forests of Alberta, Canada. Global Forest Watch Canada, Edmonton, AB

Locky DA, Bayley SE (2010) Plant diversity in wooded moderate-rich fens across boreal western Canada: an ecoregional perspective. Biodivers Conserv 19:3525-3543. https://doi.org/10.1007/s10531-010-9914-x

Loisel J et al (2014) A database and synthesis of northern peatland soil properties and Holocene carbon and nitrogen accumulation. Holocene 24:1028-1042. https://doi.org/10. 1177/0959683614538073

MacKinnon MD, Matthews JG, Shaw WH, Cuddy RG (2001) Water quality issues associated with composite tailings (CT) technology for managing oil sands tailings. Int J Surf Min Reclam Environ 15:235-256. https://doi.org/10.1076/ ijsm.15.4.235.7416

Matthews JG, Shaw WH, MacKinnon MD, Cuddy RG (2002) Development of composite tailings technology at Syncrude. Int J Surf Min Reclam Environ 16:24-39. https:// doi.org/10.1076/ijsm.16.1.24.3407

Mitsch WJ, Wang N (2000) Large-scale coastal wetland restoration on the Laurentian Great Lakes: Determining the potential for water quality improvement. Ecol Eng $15: 267-282$

Nicholls EM, Carey SK, Humphreys ER, Clark MG, Drewitt GB (2016) Multi-year water balance assessment of a newly constructed wetland, Fort McMurray, Alberta. Hydrol Process 30:2739-2753. https://doi.org/10.1002/hyp.10881

Oil Sands Wetland Working Group (2014) Guideline for wetland establishment on reclaimed oil sands leases, Cumulative Environmental Management Association. http:// cemaonline.ca/index.php/working-groups/rwg. Accessed 23 Apr 2020

Oswald CJ, Carey SK (2016) Total and methyl mercury concentrations in sediment and water of a constructed wetland in the Athabasca Oil Sands Region. Environ Pollut 213:628-637 
Purdy BG, MacDonald SE, Lieffers VJ (2005) Naturally saline boreal communities as models for reclamation of saline oil sand tailings. Restor Ecol 13:667-677. https://doi.org/10. 1111/j.1526-100X.2005.00085.x

Raab D, Bayley SE (2013) A Carex species-dominated marsh community represents the best short-term target for reclaiming wet meadow habitat following oil sands mining in Alberta, Canada. Ecol Eng 54:97-106. https://doi.org/ 10.1016/j.ecoleng.2013.01.024

Rochefort L, Vitt DH (1988) Effects of simulated acid rain on Tomenthypnum nitens and Scorpidium scorpioides in a rich fen. Bryol 91(2):121-129

Rousseaua DPL, Lesageb E, Storyc A, Vanrollegheme PA, De Pauwc N (2008) Constructed wetlands for water reclamation. Desalination 218:181-189

Sjörs H (1950) On the relation between vegetation and electrolytes in north Swedish mire waters. Oikos 2:241-258

Slack NG, Vitt DH, Horton DG (1980) Vegetation gradients of minerotrophically rich fens in western Alberta. Can J BotRev Canad De Botaniq 58:330-350

Spennato HM, Ketcheson SJ, Mendoza CA, Carey SK (2018) Water table dynamics in a constructed wetland, Fort McMurray, Alberta. Hydrol Process 32:3824-3836. https://doi.org/10.1002/hyp.13308

Stewart SA, Lemay TG (2011) Inorganic water chemistry of saline fens in northeastern Alberta (NTS 74D). Energ Resour Conserv Board, ERCB/AGS Open File Rep 2011-09, 6 p

Thullen JS, Sartoris JJ, Walton WE (2002) Effects of vegetation management in constructed wetland treatment cells on water quality and mosquito production. Ecol Eng 18:441-457

Trites M, Bayley SE (2009) Vegetation communities in continental boreal wetlands along a salinity gradient: Implications for oil sands mining reclamation. Aquat Bot 91:27-39. https://doi.org/10.1016/j.aquabot.2009.01.003

Twerdy P (2019) Hydrogeological considerations for landscape reconstruction and wetland reclamation in the sub-humid climate of northeastern Alberta, Canada. MSc thesis, Earth and Atmospheric Sciences, University of Alberta, 204 p

Vessey CJ, Lindsay MBJ, Barbour SL (2019) Sodium transport and attenuation in soil cover materials for oil sands mine reclamation. Appl Geochem 100:42-54. https://doi.org/10. 1016/j.apgeochem.2018.10.023
Vitt DH, Chee WL (1990) The relationships of vegetation to surface-water chemistry and peat chemistry in fens of Alberta, Canada. Vegetatio 89:87-106. https://doi.org/10. 1007/bf00032163

Vitt DH, House M, Hartsock JA (2016) Sandhill Fen, an initial trial for wetland species assembly on in-pit substrates: lessons after three years. Botany 94:1015-1025. https:// doi.org/10.1139/cjb-2015-0262

Volik O, Petrone RM, Hall RI, Macrae ML, Wells CM, Elmes MC, Price JS (2017) Long-term precipitation-driven salinity change in a saline, peat-forming wetland in the Athabasca Oil Sands Region, Canada: a diatom-based paleolimnological study. J Paleolimnol 58:533-550. https://doi.org/10.1007/s10933-017-9989-4

Wieder RK, Vile MA, Scott KD, Albright CM, McMillen KJ, Vitt DH, Fenn ME (2016a) Differential effects of high atmospheric $\mathrm{N}$ and $\mathrm{S}$ deposition on bog plant/lichen tissue and porewater chemistry across the Athabasca Oil Sands Region. Environ Sci Technol 50:12630-12640. https://doi. org/10.1021/acs.est.6b03109

Wieder R, Vile M, Albright C, Scott K, Vitt D, Quinn J, BurkeScoll M (2016b) Effects of altered atmospheric nutrient deposition from Alberta oil sands development on Sphagnum fuscum growth and $\mathrm{C}, \mathrm{N}$ and $\mathrm{S}$ accumulation in peat. Biogeochemistry 129. https://doi.org/10.1007/s10533016-0216-6

Wieder RK et al (2019) Experimental nitrogen addition alters structure and function of a boreal bog: critical load and thresholds revealed. Ecol Monogr 89:e01371. https://doi. org/10.1002/ecm.1371

Wytrykush C, Vitt DH, McKenna G, Vassov R (2012) Designing landscapes to support peatland development on soft tailings deposits Syncrude Canada Ltd.'s Sandhill Fen Research Watershed initiative. In: Vitt HD, Bhatti SJ (eds) Restoration and reclamation of boreal ecosystems: attaining sustainable development. Cambridge University Press, New York, p 161

Publisher's Note Springer Nature remains neutral with regard to jurisdictional claims in published maps and institutional affiliations. 